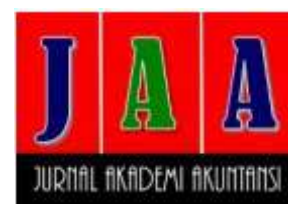

Diterima : 2 Mei 2019

Direview : 3 Mei 2019

Direvisi : 18 Mei 2019

Diterima : 20 Mei 2019

Artikel ini tersedia di website:

http://ejournal.umm.ac .id/index.php/jaa

\section{PENGARUH TEKANAN STAKEHOLDER DAN CORPORATE GOVERNANCE TERHADAP KUALITAS SUSTAINABILITY REPORT}

\author{
Rini Suharyani*, Ihyaul Ulum, Ahmad Waluya Jati \\ Program Studi Akuntansi Fakultas Ekonomi dan Bisnis \\ Universitas Muhammadiyah Malang \\ Jl. Raya Tlogomas No. 246 Malang \\ *Corresponding author: Rinisuharyani97@gmail.com
}

\begin{abstract}
The purpose of this study is to examine the effect of stakeholder pressure and corporate governance on the sustainability report quality in the companies listed on the Indonesia Stock Exchange for 2017. The research sample numbered 28 with purposive sampling technique. Data collection techniques with secondary data. Data is taken in the form of published data on the official website of the companies. Data analysis uses Content Analysis and WarpPLS 6.0. Based on the results of the study found stakeholder pressure have a significance positive effect on the sustainability report quality and corporate governance have a significance positive effect on the sustainability report quality.
\end{abstract}

Keywords: Sustainability Report, Stakeholder Pressure, Corporate Governance

\section{PENDAHULUAN}

Masalah lingkungan tidak pernah ada habisnya untuk diperbincangkan, terutama masalah lingkungan di Indonesia. Saat ini lingkungan telah terancam dengan berbagai macam aktivitas manusia. Tujuan utama dari perusahaan adalah memaksimalkan laba sekaligus kesejahteraan pemegang saham, tetapi masih banyak perusahaan yang hanya berfokus pada laba dan tidak peduli akan dampak yang ditimbulkan dari aktivitas operasinya terhadap lingkungan sekitar. Perusahaan menjadi sorotan utama dalam kontribusinya terhadap lingkungan. Seperti contoh kasus pencemaran limbah udara oleh PT. Rayon Utama Makmur Sukoharjo, masalah IPAL (Instalasi Pengolahan Air Limbah) yang tidak sesuai aturan oleh PT. Indotama, pencemaran air 
oleh PT. Energi Agro Nusantara, perluasan pabrik pengolahan limbah B3 yang berbahaya oleh PT. PRIA dan masih banyak lagi kasus lainnya, tidak hanya dampaknya terhadap lingkungan, dampak ekonomi serta kegiatan sosial yang terjadi disekitar perusahaan tersebut ikut terhenti, sehingga menimbulkan kekhawatiran masyarakat terhadap peran perusahaan dalam menjaga lingkungan. Situasi ini mendorong masyarakat untuk menuntut tanggung jawab sosial perusahaan yang lebih besar dan berkualitas.

Dari paradigma yang marak terjadi, pemerintah mengeluarkan keputusan yang kemudian diterbitkan melalui undang-undang tentang Perseroan Terbatas (PT) yang mengungkapkan berbagai ketentuan pendirian PT, salah satunya pasal 74, UU Nomor 40 tahun 2007 tentang tanggung jawab sosial dan lingkungan, UU No.23 tahun 2007 mengenai pengelolaan lingkungan hidup dan berdasarkan PP No. 27 tahun 2007 yang mengharuskan adanya AMDAL (Analisis mengenai dampak lingkungan) dari suatu proyek, yang menjadi landasan dan pedoman dalam menjalankan kegiatan ekonomi keberlanjutan dan seiring dengan ditandatanganinya pedoman penyusunan SIH (Standar Industri Hijau) Nomor 51/M-IND/PER/6/2015 oleh Menteri Perindustrian Indonesia diharapkan dapat menjadi pedoman bagi perusahaan dalam menjalankan proses produksinya yang efektif dan efisien serta ramah lingkungan. Pada tahap awal SIH ini bersifat sukarela (voluntary) namun seiring berjalannya waktu secara selektif akan bersifat wajib dan akan dikenakan sanksi pada perusahaan yang tidak memenuhi standar.

Dalam stakeholder theory, bahwa penting adanya para pemangku kepentingan dalam suatu bisnis, perusahaan dituntut untuk tidak hanya mementingkan kepentingan manajemen dan investor saja tetapi juga harus peduli terhadap karyawan, konsumen dan masyarakat karena perusahaan mempunyai tanggung jawab sosial dan lingkungan di luar dari kepentingan manajemen dan pemilik modal. Kegiatan pengelolaan pada perusahaan saat ini tidak hanya didasarkan oleh aspek ekonomi 
tetapi juga mempertimbangkan aspek sosial dan lingkungan terkait dimana perusahaan itu berada (Nasir et al., 2014), (Khafid dan Mulyaningsih, 2015).

Corporate Social Responsibility (CSR) dan laporan keberlanjutan (sustainability report) menjadi perbincangan serius beberapa dekade terakhir. Masyarakat memerlukan informasi mengenai sejauh mana perusahaan telah melaksanakan kegiatan sosialnya untuk memastikan bahwa hak-hak masyarakat sekitar telah terpenuhi (Trinanda et al., 2018). Program CSR merupakan salah satu sarana bagi perusahaan untuk menyeimbangkan keuntungan ekonomi dengan kontribusinya bagi masyarakat, sosial, dan lingkungan demi mewujudkan pembangunan yang keberlanjutan serta perusahaan dituntut untuk memberikan informasi dari setiap kegiatan yang dijalankan (Singgih et al., 2017).

Sustainability report atau laporan keberlanjutan adalah praktik pengukuran, pengungkapan dan upaya akuntabilitas dari kinerja organisasi dalam mencapai tujuan untuk pembangunan keberlanjutan kepada para pemangku kepentingan baik internal maupun eksternal perusahaan (Aziz, 2014). Selain itu sustainability report merupakan cerminan kinerja organisasi dalam dimensi ekonomi, sosial dan lingkungan yang dapat menjadi media bagi perusahaan untuk menginformasikan kinerja organisasinya kepada seluruh pemangku kepentingan, yang nantinya dapat membantu organisasi untuk menetapkan tujuan, mengukur kinerja dan mengelolah perubahan dalam rangka membuat operasi organisasi terus keberlanjutan (Sari et al., 2017). Dengan adanya pengungkapan sustainability report diharapkan dapat mencuri perhatian dalam bisnis global dan merupakan salah satu kriteria dalam menilai tanggung jawab sosial suatu perusahaan.

Badan yang mengeluarkan standar pembentukan laporan keberlanjutan terkait pengungkapan lingkungan hidup yang masih aktif hingga saat ini adalah Global Reporting Initiative (GRI). Sustainability reportatau laporan keberlanjutan memberikan informasi tentang adanya 
dampak suatu perusahaan terhadap aspek lingkungan dan sosial selain dari aspek ekonomi. GRI-standards merupakan pedoman atau standar dalam pembuatan laporan keberlanjutan. Indikator yang terdapat dalam GRI-standards dibagi menjadi 3 kategori khusus yaitu: ekonomi, lingkungan dan sosial, dengan total indikator sebanyak 77 item (GRI, 2016).

Di Indonesia pelaporan keberlanjutan atau sustainability report masih bersifat sukarela (voluntary) tidak seperti pelaporan keuangan dan pelaporan tahunan yang bersifat wajib (mandatory) terutama bagi perusahaan-perusahaan go-publik (Hasanah et al., 2015). Praktik dan pengungkapan sustainability report merupakan mekanisme dan konsekuensi nyata dari implementasi Good Corporate Covernance yang memiliki prinsip bahwa stakeholder memerlukan perhatian, baik dalam hal aturan yang ada serta menjalin kerjasama yang aktif untuk kelangsungan hidup jangka panjang antara stakeholder dengan perusahaan (Aliniar dan Wahyuni, 2017).

Tuntutan atas kualitas laporan keberlanjutan bukan hanya dari pihak eksternal (stakeholder) namun juga dari pihak internal perusahaan (corporate governance). Tata kelola yang baik dalam perusahaan mencerminkan kinerja perusahaan yang baik pula, dengan diterapkan Good Corporate Governance dalam suatu perusahaan maka perusahaan tersebut dinilai telah berupaya untuk menyampaikan seluruh informasi kepada para pemangku kepentingan termasuk laporan keberlanjutannya (sustainability report).

Pemangku kepentingan merupakan seseorang, kelompok, atau organisasi yang memiliki ketertarikan atau kepentingan dalam organisasi tertentu (Rudyanto dan Siregar, 2018). Tanpa adanya dukungan dari para pemangku kepentingan (stakeholder) perusahaan tidak dapat menjalankan usahanya dan setiap klasifikasi industri memiliki pemangku kepentingan (stakeholder) yang berbeda-beda (Fernandez-Feijoo et al., 2012). Tekanan yang diberikan oleh para pemangku kepentingan 
menuntut adanya pelaksanaan dan pengkomunikasian dari kegiatan tanggung jawab sosial perusahaan dalam bentuk laporan, tidak hanya dalam bentuk laporan saja tetapi dalam bentuk laporan yang berkualitas. Jenis laporan yang dimaksud yang paling lengkap, komprehensif dan merupakan jenis laporan sukarela yaitu laporan keberlanjutan (sustainability report) (Rudyanto dan Siregar, 2018). Penelitian tentang pengaruh tekanan stakeholder dan corporate governance terhadap pengungkapan sustainability report hanya menunjukan dampaknya terhadap kuantitas bukan kualitas.

\section{TINJAUAN TEORI DAN PENGEMBANGAN HIPOTESIS Teori Stakeholder}

Teori Teori stakeholder menyatakan bahwa perusahaan selain adanya struktur dan proses yang digunakan oleh organ perusahaan untuk meningkatkan keberhasilan usaha dan akuntabilitas perusahaan dengan tetap memperhatikan kepentingan stakeholder, perusahaan bukanlah badan yang beroperasi hanya untuk kepentingan sendiri, tetapi tujuan perusahaan adalah memenuhi kebutuhan para pemangku kepentingan (stakeholder). Kelangsungan hidup perusahaan dipengaruhi oleh para stakeholder, dan setiap perusahaan memiliki stakeholder yang berbeda-beda (FernandezFeijoo et al., 2012). Teori stakeholder merupakan konsep manajemen strategis yang nantinya dapat membantu perusahaan atau badan usaha memperkuat hubungan dengan pihak eksternal dan mengembangkan keunggulan kompetitif.

Dalam perkembangan stakeholder theory yang dikembangkan oleh Freeman (1984) menilai adanya hubungan antara perusahaan dan kelompok yang berbeda selain pemegang saham, bahwa para pemangku kepentingan dapat atau hampir selalu mempengaruhi atau dipengaruhi oleh tindakan perusahaan. Sutedi (2012: 39) teori stakeholder adalah ide tentang bagaimana suatu bisnis benar-benar bekerja, untuk setiap bisnis yang akan sukses harus menciptakan nilai bagi pelanggan, karyawan, masyarakat, dan 
pemilik modal. Selanjutnya Carroll (1991) menyatakan bahwa adanya kaitan alami antara CSR dan stakeholder perusahaan. Oleh karena itu erat kaitanya antara laporan keberlanjutan dengan kekuatan atau komitmen dari stakeholder dalam suatu industri (Hamudiana dan Achmad, 2017).

\section{Sustainability Report}

Sustainability report atau laporan keberlanjutan merupakan praktik pengukuran, pengungkapan dan upaya akuntabilitas dari kinerja organisasi untuk mencapai pembangunan yang berkelanjutan. Sustainability report merupakan sumbangasih perusahaan kepada masyarakat yang dilihat dari tiga aspek yaitu ekonomi, sosial dan lingkungan yang menggambarkan kepedulian perusahaan terhadap masyarakat mengenai aspek-aspek yang dilaporkannya dan sekaligus menjembatani kebutuhan para pemangku kepentingan (stakeholder) dalam rangka pengambilan keputusan.

Saat ini organisasi yang masih aktif mengeluarkan pedoman atau standar terkait kerangka kerja laporan keberlanjutan adalah Global Reporting Initiative (GRI). Sustainability report mempunyai standar pengungkapan yang mencerminkan keseluruhan aktivitas sosial perusahaan dengan adanya sustainability report ini kinerja suatu perusahaan dapat dinilai langsung oleh pemerintah, masyarakat, organisasi lingkungan, media masa, serta para investor maupun kreditor.

Dalam standar GRI-standards 2016 terdapat dua jenis pengungkapan standar, yaitu pengungkapan umum dan pengungkapan khusus. Pengungkapan umum memuat mengenai strategi dan analisis perusahaan, profil perusahaan, identifikasi aspek material bagi perusahaan, hubungan dengan pemangku kepentingan, profil laporan, dan tata kelola perusahaan. Sedangkan pengungkapan khusus mencakup pengungkapan mengenai kinerja ekonomi, kinerja lingkungan, dan kinerja sosial. Dimana saat ini digunakan standar GRI-standards yang terbagi dalam tiga indikator yaitu sosial, lingkungan dan ekonomi dengan total indikator sebanyak 77 item 
dimana 13 untuk kategori ekonomi, 30 kategori lingkungan dan 34 kategori sosial (GRI, 2016).

Kualitas sustainability report dalam penelitian ini diukur dengan strandar GRI-standards yaitu standar terbaru atas kelengkapan laporan keberlanjutan yang dipublish oleh perusahaan, semakin lengkap informasi yang diungkapkan oleh perusahaan menjadikan laporan keberlanjutan dinilai lebih berkualitas. Suatu pengungkapan dikatakan berkualitas apabila stakeholder telah dapat menerima manfaat dari pengungkapan tersebut, serta suatu laporan dapat dikatakan berkualitas apabila dapat memudahkan para pemangku kepentingan dalam memahami laporan sustainability report yang nantinya untuk pengambilan keputusan jangka panjang yang berkelanjutan.

\section{Tekanan Stakeholder dan Kualitas Sustainability Report}

Stakeholder merupakan bagian penting dari perusahaan, suatu perusahaan tidak dapat beroperasi tanpa adanya stakeholder. Kelangsungan hidup perusahaan sangat dipengaruhi oleh para pemangku kepentingan. Faktor-faktor yang diperkirakan bahwa suatu perusahaan melaporkan laporan keberlanjutannya yaitu akibat dari adanya tekanan dari stakeholder. Penelitian yang telah dilakukan oleh Fernandez-Feijoo et al. (2012), Hamudiana dan Achmad (2017) dan Rudyanto dan Siregar (2018) diproksikan dengan empat indikator berdasarkan primary stakeholder yaitu Industri Sensitif Lingkungan (Environmentally Sensitive Industry/ESI), Industri Dekat Konsumen (Consumer-Proximity Industry/CPI), Industri Berorientasi Investor (Investor-Oriented Industry/IOI) dan Industri Berorientasi Pekerja/Karyawan (Employee-Oriented Industry/EOI.

Fernandez-Feijoo et al. (2012) menyatakan bahwa industri berorientasi investor dan pekerja berpengaruh paling tinggi dan industri sensitif lingkungan berpengaruh paling rendah terhadap transparansi dan pengungkapan sustainability report. Sejalan dengan hasil penelitian lainnya, bahwa industri berorientasi investor dan pekerja/karyawan berpengaruh 
paling tinggi terhadap transparansi sustainability report. Perusahaan dengan tekanan dari lingkungan yang tinggi mendorong perusahaan untuk melaporkan laporan keberlanjutannya secara lebih transparan. Tekanan dari karyawan yang tinggi membuat perusahaan menghasilkan laporan keberlanjutannya yang lebih transparan, semakin banyaknya jumlah pekerja/karyawan maka semakin banyak jumlah pekerja maka semakin tinggi pula tingkat transparansi yang mereka minta. Sama halnya dengan perusahaan yang memiliki tekanan investor tinggi akan menghasilkan tingkat transparansi laporan keberlanjutan yang tinggi pula karena mengindikasi adanya tekanan dari pasar modal untuk menaikan tingkat kepercayaan dari para investor dengan cara meningkatkan level transparansi pelaporan. besar. $\mathrm{H}_{1}=$ Tekanan stakeholder berpengaruh terhadap kualitas sustainability report.

\section{Corporate Governance dan Kualitas Sustainability Report}

Corporate governance adalah suatu sistem, proses dan seperangkat peraturan yang mengatur hubungan antara berbagai pihak yang berkepentingan (stakeholder) demi tercapainya tujuan organisasi. Corporate governance merupakan struktur yang digunakan oleh organ perusahaan untuk menentukan kebijakan yang digunakan dalam meningkatkan keberhasilan usaha serta akuntabilitas perseroan sesuai dengan prinsip GCG. Dengan diterapkannya Good Corporate Governance dalam suatu perusahaan, maka perusahaan tersebut dinilai telah berupaya menyampaikan seluruh informasi kepada para pemangku kepentingan termasuk laporan keberlanjutannya (sustainability report). Dalam penelitian ini corporate governance diproksikan dengan menggunakan jumlah rapat atau pertemuan dewan direksi, jumlah rapat atau pertemuan dewan komisaris, proporsi komisaris independen, jumlah rapat atau pertemuan komite audit dan ada tidaknya kepemilikan saham manajerial yang diungkapkan. Dewan direksi dalam corporate governance merupakan organ yang memiliki tanggung jawab penuh atas pengelolaan perusahaan sedangkan dewan komisaris melakukan pengawasan yaitu memonitoring dan 
mengontrol manajemen operasioanal perusahaan serta memberi nasihat kepada Direksi. Komite audit merupakan komite yang dibentuk oleh dewan komisaris untuk membantu dalam menjalankan fungsi pengawasan terhadap kinerja Direksi dan Tim Manajemen sesuai dengan prinsip GCG. Kepemilikan saham manajerial dibentuk agar dapat mengurangi konflik antara manajemen dan pemilik, dengan adanya prinsip yang memberlakukan bahwa adanya kesetaraan antara manajer dan pemegang saham dilakukan agar manajemen ikut serta secara aktif dalam pengambilan keputusan sekaligus memotivasi manajer untuk meningkatkan kinerjanya.

$\mathrm{H}_{2}=$ Corporate governance berpengaruh terhadap kualitas sustaianability report

\section{METODE}

Jenis penelitian yang digunakan dalam penelitian ini adalah jenis penelitian asosiatif yaitu dengan menganalisis hubungan variabel yang satu dengan variabel lainnya. Variabel independen dalam penelitian ini adalah tekanan stakeholder dan corporate governance sedangakan variabel dependen yaitu kualitas sustainability report.

Populasi dalam penelitian ini adalah perusahaan-perusahaan yang mempublikasikan sustainability report tahun 2017. Jenis sampel yang diambil dengan menggunakan purposive sampling dengan kriteria sebagai berikut:

1. Perusahaan yang mempublikasikan sustainability report tahun 2017.

2. Perusahaan yang mempublikasikan annual report dan sustainability report secara terpisah selama tahun 2017.

3. Perusahaan yang mengungkapkan sustainability report menggunakan standar GRI-standards.

4. Perusahaan yang mempublikasikan annual report dan sustainability reportyang dapat diakses.

\section{Variabel Dependen}

Pengukuran kualitas sustainability report diukur dengan menggunakan content analysis berdasarkan GRI-standards. Pemberian 
bobot pada content analysis berdasakan pada kelengkapan laporan yang diungkapkan yaitu sebagai berikut:

Tabel Penilaiaan Kualitas Sustainability Report

\begin{tabular}{cl} 
Bobot & \multicolumn{1}{c}{ Keterangan } \\
0 & Komponen yang tidak diungkapkan \\
\hline 1 & Komponen yang diungkapkan secara kualitatif \\
2 & Komponen yang diungkapkan secara kuantitatif
\end{tabular}

Hasil pengunkapan item yang dianalisis dari setiap perusahaan dengan pemberian bobot dihitung dengan rumus:

$$
\text { DISCGRI }=\frac{\text { Jumlah skor yang diungkapkan }}{\text { Jumlah skor maksimal yang diharapkan }}
$$

\section{Variabel Independen}

Pengukuran tekanan stakeholder diproksikan berdasarkan primary stakeholder yaitu lingkungan, konsumen, investor dan karyawan. Industri Sensitif Lingkungan (Environmentally Sensitive Industry/ESI) memberi penilaian berdasarkan aspek kategori lingkungan yang diungkapkan dalam laporan keberlanjutan perusahaan yang terdiri dari 30 indikator. Industri Dekat Konsumen (Consumer-Proximity Industry/CPI) memberi penilaian berdasarkan aspek kategori sosial yang diungkapkan dalam laporan keberlanjutan perusahaan yang terdiri dari 3 indikator yaitu tentang kesehatan dan keselamatan pelanggan dan privasi pelanggan. Industri Berorientasi Investor (Investor-Oriented Industry/IOI) mengunakan pengukuran dari Thomsen et al. (2006) dan (Rudyanto dan Siregar, 2018) yaitu dengan tingkat konsentrasi struktur kepemilikan. Tingkat konsentrasi diukur dengan perbandingan jumlah saham yang dimiliki oleh perusahaan induk dengan jumlah saham keseluruhan perusahaan. Industri Berorientasi Pekerja/Karyawan (Employee-Oriented Industry/EOI) memberi penilaian berdasarkan aspek kategori sosial yang diungkapkan dalam laporan keberlanjutan perusahaan yang terdiri dari 17 indikator mengenai karyawan/pekerja.

Pengukuran corporate governance yaitu dewan direksi, dewan komisaris dan komite audit menggunakan frekuensi kehadiran rapat, proporsi komisaris independen dan komposisi kepemilikan saham manajerial. 


\section{HASIL DAN PEMBAHASAN}

Objek penelitian yang digunakan pada penelitian ini adalah seluruh perusahaan yang mempublikasikan sustainability report pada tahun 2017 dengan total perusahaan sebanyak 41 perusahaan. Dari total perusahaan yang mempublish sustainability report hanya 28 perusahaan yang memenuhi kriteria yang dapat ditetapkan menjadi.

Dalam pengujian hipotesis dengan WarpPLS terdapat dua tahapan yang harus dilakukan, yaitu yang pertama menilai outer model serta menilai inner model (structural model), setelah kedua syarat tersebut terpenuhi maka pengujian hipotesis dapat dilakukan (Sholihin dan Ratmono, 2013).

a. Penilaian outer model atau measurement model

Analisis outer model dengan model indikator formatif yaitu dengan syarat uji significance of weight. Uji significance of weight adalah untuk mengetahui nilai signifikan indikator dengan variable. Tingkat signifikan yaitu dengan syarat $\mathrm{P}-$ Value dibawah 0,05 .

\section{Tabel Hasil Indicator Weight}

\begin{tabular}{ccccc}
\hline Variabel & Indikator & Nilai koefisien & P Value & VIF \\
\hline $\begin{array}{c}\text { Kualitas } \\
\text { Sustainability } \\
\text { Report }\end{array}$ & DISCGRI & 1.000 & $<0.001$ & 0.000 \\
& & & &
\end{tabular}

Sumber: data diolah tahun 2019

Berdasarkan tabel indicator weight, variabel kualitas sustainability report telah memenuhi syarat uji significance of weight dilihat dari nilai P-value DISCGRI $<0.001$ dan nilai VIF senilai 0.000 karena untuk pengukuran variabel kualitas sustainability report hanya menggunakan satu indikator.

Analisis outer model untuk indikator reflektif yaitu dengan uji reliabilitas dengan syarat melihat nilai composite reliability $\geq 0,5$ maka variabel tersebut telah reliable.

Tabel Hasil Uji Reliabilitas 


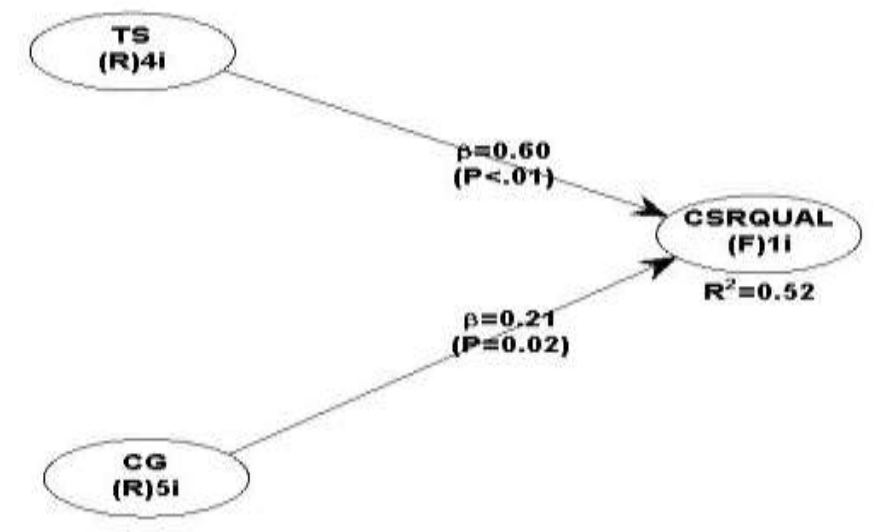

Gambar Output WarpPLS 6.0

\begin{tabular}{cccc}
\hline Variabel & Indikator & $\begin{array}{c}\text { Composite } \\
\text { Reliability }\end{array}$ & Keterangan \\
\hline Tekanan & ESI & \multirow{2}{*}{0.50} & Reliabel \\
Stakeholder & CPI & & $\begin{array}{l}\text { Reliabel } \\
\text { Reliabel } \\
\text { Reliabel }\end{array}$ \\
\hline & IOI & & Reliabel \\
& EOI & & Reliabel \\
Corporate & DK & & Reliabel \\
Governance & DD & \multirow{2}{*}{0.69} & Reliabel \\
& KA & & Reliabel \\
\hline
\end{tabular}

Sumber: data diolah tahun 2019

Berdasarkan tabel hasil uji reliabilitas indikator reflektif, variabel tekanan stakeholder dan corporate governance telah memenuhi syarat uji reliabilitas. Dimana composite reliability untuk tekanan stakeholder yaitu senilai 0.50 dan corporate governance senilai 0.69 yang artinya reliable.

b. Penilaian inner model atau struktural model 
Dalam pengujian inner model yaitu dengan melihat nilai Adjusted $R$ squared. Semakin besar nilai Adjusted $R$-squared menunjukan semakin baik model prediksi dari model penelitian yang diajukan. Kemudian nilai Q-squared untuk menunjukan seberapa baik nilai observasi dihasilkan dari model, nilai Q-squared yang lebih besar dari nol menunjukan predictive relevance begitupun sebaliknya.

\section{Tabel Nilai Adjusted $R$-square dan $Q$-squared}

\begin{tabular}{ccc}
\hline Variabel & Adjusted $R$-squared & $Q$-squared \\
\hline Kualitas Sustainability & 0.480 & 0.495 \\
Report &
\end{tabular}

Sumber: data diolah tahun 2019

Berdasarkan tabel nilai Adjusted $R$-squared sebesar 0.480 yang menunjukan bahwa tekanan stakeholder dan corporate governance dapat menjelaskan varian dari kualitas sustainability reportsebesar $48 \%$, lalu selebihnya sebesar 52\% dipengaruhi oleh variabel diluar model penelitian. Kemudian nilai $Q$-squared sebesar $49 \%$ yang artinya menunjukan prediktif yang baik karena $Q$-squared lebih dari nol.

Dalam model pengujian hipotesis untuk menguji hubungan antara variabel independen dan variabel dependen. Berdasarkan gambar output WarpPLS, diperoleh hasil pengujian hipotesis sebagai berikut:

\section{Tabel Hasil Uji Hipotesis Pengaruh}

\begin{tabular}{|c|c|c|c|c|c|}
\hline Hipotesis & Keterangan & $\begin{array}{l}\text { Nilai } \\
\text { Koefisien } \\
\text { Jalur }\end{array}$ & $\begin{array}{c}\mathrm{P} \\
\text { Value }\end{array}$ & $\begin{array}{c}\text { Interpretasi } \\
\text { arah dan } \\
\text { signifikansi }\end{array}$ & Keputusan \\
\hline $\mathrm{H}_{1}$ & TS $\rightarrow$ CSRQUAL & 0.60 & $<0.01$ & $\begin{array}{l}\text { Positif, } \\
\text { signifikan }\end{array}$ & Diterima \\
\hline $\mathrm{H}_{2}$ & CG $\rightarrow$ CSRQUAL & 0.21 & 0.02 & $\begin{array}{l}\text { Positif, } \\
\text { signifikan }\end{array}$ & Diterima \\
\hline
\end{tabular}

Sumber: data diolah tahun 2019

Berdasarkan tabel hasil uji hipotesis, $\mathrm{H}_{1}$ diterima dengan nilai koefisien positif sebesar 0.60 dengan $P$ value $<0.01$ yaitu dibawah 0.05 yang artinya berpengaruh positif signifikan. Kemudian $\mathrm{H}_{2}$ diterima 
dengan nilai koefisien positif sebesar 0.21 dengan $P$ value 0.02 yang artinya berpengaruh positif signifikan.

Model persamaan struktural dalam hipotesis penelitian ini yang menjelaskan hubungan antar konstruk adalah sebagai berikut:

$$
\begin{aligned}
\eta & =\beta_{1} \xi_{1}+\beta_{2} \xi_{2}+\zeta \\
\text { CSRQUAL } & =0.60 \mathrm{TS}+0.21 \mathrm{CG}+\zeta
\end{aligned}
$$

\section{Pengaruh tekanan stakeholder terhadap kualitas sustainability report}

Berdasarkan hasil pengujian secara simultan, hipotesis pertama diterima dengan tanda nilai koefisien positif signifikan. Hal tersebut menunjukan bahwa semakin besar tekanan dari stakeholder maka semakin baik kualitas sustainability report yang diungkapkan maupun sebaliknya semakin rendah tekanan yang diberikan stakeholder maka semakin rendah kualitas sustainability report yang diungkapkan perusahaan. Hal tersebut mendukung penelitian yang dilakukan Fernandez-Feijoo et al. (2012) dan Simbolon dan Sueb (2016), Hamudiana dan Achmad (2017) dan Rudyanto dan Siregar (2018) hal ini tidak sejalan dengan penelitian Kurniawan et al. (2018) yang menyatakan bahwa kategori sosial yang yang terdiri dari pekerja dan masyarakat tidak berhubungan langsung terhadap pengungkapan sustainability report. Hal ini terjadi karena perbedaan objek pengukuran yang digunakan.

Adanya perbedaan pengukuran antar peniliti satu dengan yang lainnya, dimana Hamudiana dan Achmad (2017) menggunakan pengukuran dummy untuk industri sensitif lingkungan, dekat konsumen, berorientasi investor dan berorientasi karyawan/pekerja. Sedangkan, Rudyanto dan Siregar (2018) menggunakan pengukuran dummy untuk indikator industri sensitif lingkungan dan industri dekat konsumen, kemudian indikator berorientasi investor menggunakan pengukuran dengan mengukur proporsi jumlah saham induk dan 
industri berorientasi karyawan/pekerja menggunakan total jumlah karyawan.

Dalam stakeholder theory, agar suatu perusahaan dapat bertahan, perusahaan harus dapat memberikan nilai ekonomis dan non ekonimis kepada para pemangku kepentingannya, salah satu wujud nilai tersebut adalah dengan melakukan CSR, dimana CSR tersebut dilaporkan dalam sustainability report.

Hasil pengujian hipotesis $\left(\mathrm{H}_{1}\right)$ telah sesuai dengan teori stakeholder dimana perusahaan yang memiliki tekanan stakeholder yang tinggi membuat perusahaan tersebut dapat meyakinkan bahwa aktivitas serta kinerjanya dapat diterima dan dipercaya oleh masyarakat melalui laporan keberlanjutan perusahaan. Industri dengan orientasi karyawan/pekerja yang tinggi akan cenderung memotivasi karyawan dan memandang bahwa perusahaan telah memenuhi hak-hak karyawannya, kemudian industri orientasi karyawan/pekerja yang tinggi akan menurunkan tingkat perputaran karyawan sehingga pada akhirnya dapat meningkatkan produktivitas perusahaan. Industri sensitif lingkungan cenderung mengungkapkan laporan yang berkualitas, hal ini tidak lepas dari tekanan dari para pencinta lingkungan dan masyarakat yang menuntut perusahaan agar dapat meperbaiki lingkungan yang timbul akibat aktivitas operasi perusahaan, oleh karena tuntutan tersebut perusahaan berusaha untuk melakukan tanggung jawab sosial dan mengungkapkannya dengan lebih transparan. Industri dengan orientasi investor membuat perusahaan menjadi lebih transparan dalam mengungkapkan informasi yang berkualitas, suatu laporan akan diberi respon positif oleh investor jika mampu memberikan suatu kandungan informasi, dimana kandungan informasi yang diharapkan adalah kemampuan sustainability report untuk dapat membantu investor memprediksi kemampuan bertahan perusahaan dimasa mendatang (Jenawan dan Juniarti, 2015). Perusahaan yang melakukan aktivitas voluntary 
seperti CSR akan mendapatkan respon positif dari investor, aktivitas voluntaryakan menjadi indikator investor bahwa perusahaan tersebut sedang beroperasi dengan baik dan perusahaan yang memiliki reputasi sebagai perusahaan yang bertanggung jawab kepada sosial dan lingkungan akan lebih dihargai oleh investor ketika terjadi krisis.

Hasil penelitian yang dilakukan Fernandez-Feijoo et al. (2012) menyatakan bahwa investor berpengaruh paling tinggi terhadap kualitas sustainability report perusahaan. Simbolon dan Sueb (2016) menyatakan bahwa pengungkapan sustainability report kategori sosial akan berdampak pada presepsi stakeholder tentang perlakuan perusahaan terhadap sumber daya disekitarnya sehingga akan menjadi nilai lebih di mata investor. Kategori sosial dalam laporan keberlanjutan berfokus pada hubungan langsung perusahaan dengan stakeholder yang terdiri dari karywan/pekerja dan masyarakat dalam hal ini khususnya konsumen..

Kualitas sustainability report dengan skor tertinggi yaitu pada PT. Smart Tbk, yang memfokuskan kualitas sustainability report pada kategori pengungkapan lingkungan (303-1,303-3,304-1, 304-2,3043, 304-4, 305-4, 305-5, 306-2, 308-1, 308-2) dan kategori sosial (4011,401-2,403-2, 404-1, 404-3, 405-1, 406-1, 408-1, 409-1, 410-1, 4111, 412-1, 412-2, 413-1, 414-1, 414-2, 415-1, 416-1). Sementara, kualitas sustainability report dengan skor terendah oleh PT. Bank Mandiri Tbk, yang hanya memfokuskan pada kategori ekonomi (2011, 203-1) dan kategori sosial khususnya berorientasi konsumen (4131, 418-1). Kemudian kualitas pengungkapan dengan skor tertinggi untuk kategori ekonomi yaitu pada PT. Bank Pembangunan Daerah Jawa Barat dan Banten Tbk, dengan presentase 50\%, kategori lingkungan dan sosial pada PT. Smart Tbk, dengan presentase 30\% dan $37 \%$

\section{Pengaruh corporate governance terhadap kualitas sustainability report}


Berdasarkan hasil pengujian secara simultan, hipotesis kedua diterima dengan tanda nilai koefisien positif signifikan. Hal tersebut menunjukan bahwa semakin baik tata kelola dalam perusahaan maka semakin baik kualitas sustainability report yang diungkapkan. Hal tersebut mendukung penelitian yang dilakukan Sari dan Marsono (2013), Aziz (2014), Aliniar dan Wahyuni (2017), dan Siregar (2017), hasil penelitian ini tidak sejalan dengan penelitian yang dilakukan, Nasir et al. (2014), Hasanah et al. (2015) dan Wulanda (2017) yang menyatakan bahwa corporate governance dengan indikator dewan direksi, dewan komisaris, komite audit, komisaris independen dan kepemilikan saham manajerial berpengaruh tidak signifikan terhadap sustainability report.

Hal tersebut terjadi karena perbedaan pengukuran indikator dan sampel dalam penelitian. Nasir et al. (2014) mengambil sampel pada perusahaan yang terdaftar di LQ45 dengan jumlah anggota dewan direksi dan komite audit sebagai pengukuran indikator corporate governance. Kemudian, Hasanah et al. (2015) memperoleh 30 sampel pada seluruh perusahaan yang terdaftar di BEI dengan rata-rata kehadiran rapat dewan direksi, dewan komisaris dan komite audit sebagai pengukuran indikator corporate governance. Sedangkan, Wulanda (2017) memperoleh 12 sampel pada perusahaan yang terdaftar di LQ45 selama tahun 2011-2014 dengan jumlah anggota dewan direksi dan komite audit sebagai pengukuran indikator corporate governance.

Stakeholder theory menyatakan corporate governance sebagai suatu proses dan struktur yang digunakan oleh organ perusahaan untuk meningkatkan keberhasilan usaha dan akuntabilitas perusahaan dengan tetap meperhatikan kepentingan dari seluruh stakeholder bukan hanya terbatas kepada satu stakeholder saja (Sutedi, 2012, 1), dengan adanya good corporate governance akan menciptakan nilai tambah (value added) untuk semua stakeholder dan akan 
memberikan pengungkapan secara luas yang transparan terhadap seluruh stakeholder yang berkepentingan yang membutuhkan informasi mengenai perusahaan. Pengungkapan informasi yang memadai sangat diperlukan oleh investor dalam kemampuannya untuk membuat keputusan, perusahaan dalam hal ini harus meningkatkan kualitas dan kuantitas pengungkapan informasi agar dapat menarik para stakeholder sehingga tercapai tujuan suatu perusahaan.

Hasil uji hipotesis $\left(\mathrm{H}_{2}\right)$ telah sesuai dengan teori stakeholder dimana perusahaan yang memiliki tata kelola yang baik menghasilkan pengungkapan sustainability report yang berkualitas sehingga dapat memberi sinyal positif bagi para stakeholder. Kinerja dewan direksi yang baik akan mampu mewujudkan Good Corporate Governance bagi perusahaan. Dalam GCG, kepemilikan saham manajerial dibentuk agar adanya kesetaraan antara pemegang saham dengan manajemen, sehingga dapat mendorong manajemen untuk meningkatkan kinerjanya untuk melakukan pengungkapan informasi yang lebih baik dan berkualitas. Selain mengungkapkan informasi yang bersifat mandatory juga mengungkapkan informasi yang bersifat voluntary yaitu sustainability report.

Kemudian, hasil penelitian yang dilakukan oleh Sari dan Marsono (2013) bahwa semakin tinggi frekuensi kehadiran rapat komite audit maka koordinasi dan hubungan antar komite audit semakin baik sehingga dapat melaksanakan pengawasan terhadap manajemen yang pada akhirnya mendukung kualitas pengungkapan laporan keberlanjutan yang dilakukan perusahaan, Aziz (2014) menyatakan bahwa adanya kepemilikan saham manajerial menjadikan manajer semakin termotivasi dan meningkatkan kinerjanya termasuk dalam meningkatkan kualitas laporan informasi yang bersifat voluntary yaitu sustainability report. 
Kualitas pengungkapan sustainability report yang tertinggi oleh PT. Smart Tbk yaitu sebanyak 30\% dengan nilai presentase kehadiran rapat dewan direksi $98 \%$, dewan komisaris $100 \%$, komite audit $100 \%$, proporsi komisaris independen $50 \%$ artinya sesuai peraturan yang beralaku adalah diatas $30 \%$, dan kepemilikan saham manajerial sebesar $0,0000087 \%$. Sementara kualitas sustainability report terendah oleh PT. Bank Mandiri Tbk yaitu sebanyak 6\% dengan nilai presentase rapat dewan direksi $88 \%$, dewan komisaris $91 \%$, komite audit $90 \%$, proporsi komisaris independen $50 \%$, dan kepemilikan saham manajerial 0,0088986\%

\section{SIMPULAN}

Berdasarkan penelitian yang telah dilakukan mengenai pengaruh tekanan stakeholder dan corporate governance terhadap kualitas sustainability report. Penelitian ini membuktikan bahwa tekanan stakeholder berpengaruh positif signifikan terhadap kualitas sustainability report telah sesuai dengan teori stakeholder. Dimana lingkungan, konsumen, pekerja dan investor dapat mendorong perusahaan untuk mengungkapkan sustainability report yang lebih berkualitas dan bernilai bagi masyarakat luas. Tekanan dari stakeholder yang tinggi membuat perusahaan berusaha melakukan tanggung jawab sosialnya dan mengungkapkannya dengan lebih transparan demi keberlangsungan hidup perusahaan jangka panjang.

Penelitian ini juga membuktikan bahwa corporate governance berpengaruh positif terhadap kualitas sustainability report telah sesuai dengan teori stakeholder, dimana perusahaan dengan tingkat frekuensi kehadiran rapat dewan direksi, dewan komisari, komite audit yang tinggi dengan proporsi komisaris independen dan adanya kepemilikan saham manajerial, dapat menjamin pengendalian serta mendorong pihak manajemen untuk mengungkapkan sustainability report yang berkualitas. 


\section{Keterbatasan Penelitian}

Penelitian ini memiliki keterbatasan yang dapat menjadi arah bagi peneliti selanjutnya.. Pada tahun 2017, sustainability report masih berada pada tahap pengalihan yang nantinya akan bersifat mandatory (wajib) sehingga belum semua perusahaan mempublikasikan sustainability reportnya, apabila peneliti hanya memfokuskan pada satu sektor industri, sampel data yang diperoleh akan sangat sedikit.

Disamping itu, terdapat perusahaan yang sustainability reportnya tidak dapat diakses pada saat pengambilan data sampel. Berdasarkan hasil uji Adjusted $R$-squared variabel tekanan stakeholder dan corporate governance hanya mampu menjelaskan variabel kualitas sustainability report sebesar $48 \%$, artinya masih ada $52 \%$ indikator lain diluar indikator yang diteliti yang dapat menjelaskan kualitas sustainability report.

\section{Saran}

Berdasarkan keterbatasan peneliti yang telah diungkapkan, untuk tahun berikutnya sustainability report di Indonesia telah bersifat mandatory (wajib) maka untuk peneliti selanjutnya dapat memfokuskan pada satu sektor industri serta menambahkan variabel lain yang dapat mempengaruhi kualitas susatainability report. 


\section{Daftar Pustaka}

Aliniar, D., dan S. Wahyuni. 2017. "Pengaruh Mekanisme Good Corporate Governance (GCG) dan Ukuran Perusahaan Terhadap Kualitas dan Pengungkapan Sustainability Report pada Perusahaan Terdaftar di BEI". Kompartemen, Vol. 15, No. 1, hlm.

Aziz, A. 2014. "Analisis Pengaruh Good Corporate Governance (GCG) Terhadap Kualitas Pengungkapan Sustainability Report". Jurnal Audit dan Akuntansi, Vol. 3, No. 2, hlm: 65-84.

BAPEPAM. 2001. Keputusan Direksi Pt Bursa Efek Jakarta No: KEP315/BEJ/07-2001 tentang Ketentuan Umum Pencatatan Efek Bersifat Ekuitas di Bursa.

Carroll, A. B. 1991. "The Pyramid of Corporate Social Responsibility: Toward the Moral Management of Organizational Stakeholders". Business Horizons, Vol. 34, No. 3, hlm: 39-48.

Fernandez-Feijoo, B., S. Romero, dan S. Ruiz. 2012. "Effect of Stakeholders' Pressure on Transparency of Sustainability Reports within the GRI Framework ". Journals of Bussiness Ethics, Vol., No. 122, hlm: 5363.

GRI. 2016. Sustainability Report Disclosure Standart.

Hamudiana, A., dan T. Achmad. 2017. "Pengaruh Tekanan Stakeholder Terhadap Transparansi Laporan Berkelanjutan PerusahaanPerusahaan di Indonesia". Journals of Accounting, Vol. 6, No. 4, hlm: 1-11.

Hasanah, N. m., D. Syam, dan A. W. Jati. 2015. "Pengaruh Corporate Governance terhadap Pengungkapan Sustainability Report pada Perusahaan di Indonesia". Jurnal Reviu Akuntansi Keuangan, Vol. 5, No. 1, hlm: 771-720.

Indonesia, R. 2007. Undang-Undang No. 40 Tahun 2007 tentang Perseroan Terbatas

Jenawan, S., dan Juniarti. 2015. "Pengaruh Pengungkapan Sustainability Reporting terhadap Respon Investor". Business Accounting Review, Vol. 3, No. 1, hlm.

Khafid, M., dan Mulyaningsih. 2015. "Kontribusi Karakteristik Perusahaan dan Corporate Governance Terhadap Publikasi Sustainability Report". Jurnal Ekonomi dan Keuangan, Vol. 19, No. 3, hlm: 340-359.

Kurniawan, T., H. Sofyani, dan E. Rahmawati. 2018. "Pengungkapan Sustainability Report dan Nilai Perusahan: Studi Empiris di Indonesia dan Singapura". Jurnal Ilmiah Akuntansi, Vol. 16, No. 1, hlm: 1-20.

Nasir, A., E. Ilham, dan V. I. Utara. 2014. "Pengaruh Karakteristik Perusahaan dan Corporate Governance Terhadap Pengungkapan Sustainability Report pada Perusahaan LQ45 yang Terdaftar". Jurnal Ekonomi, Vol. 22, No. 1, hlm.

Perindustrian, K. 2015. Pedoman Standar Penyusunan Industri Hijau (SIH). 
Rudyanto, A., dan S. V. Siregar. 2018. "The Effect of Stakeholder Pressure and Corporate Governance on the Quality of Sustainability Report ". International Journal of Ethics and Systems, Vol., No., hlm.

Sari, M. P. Y., dan Marsono. 2013. "Pengaruh Kinerja Keuangan, Ukuran Perusahaan dan Corporate Governance Terhadap Pengungkapan Sustainability Report". Journal of Accounting, Vol. 2, No. 3, hlm: 110.

Sari, N. A., B. Artinah, dan Safriansyah. 2017. "Sustainability Report dan Nilai Perusahaan di Bursa Efek Indonesia". Jurnal Spread, Vol. 7, No. 1, hlm.

Sholihin, M., dan D. Ratmono. 2013. Analisis SEM-PLS dengan WarpPLS3.0 untuk Hubungan Nonlinier dalam Penelitian Sosial dan Bisnis. Yogyakarta: Andi Offset.

Simbolon, J., dan M. Sueb. 2016. "Pengaruh Pengungkapan Sustainability Report Terhadap Kinerja Keuangan Perusahaan (Studi Empiris pada Perusahaan Tambang dan Infrastruktur Subsektor Energi yang Terdaftar di BEI Tahun 2010-2014)". Simposium Nasional Akuntansi $X I X$, Vol., No., hlm: 1-30.

Singgih, M., L. Farida, dan R. A. Iwanda. 2017. "Determinan Tingkat Pengungkapan Tanggung Jawab Sosial Perusahaan Manufaktur Sub Sektor Makanan Dan Minuman di BEI". Bisnis dan Manajemen, Vol. 11, No. 3, hlm: 259-270.

Siregar, R. M. M. 2017. "Pengaruh Good Corporate Governance Dan Kepemilikan Saham Publik Terhadap Tingkat Pengungkapan Corporate Social Responsibility". Jurnal Profita, Vol. 6, No. 2, hlm.

Sutedi, A. 2012. Good Corporate Governance. Jakarta: Sinar Grafika.

Thomsen, S., T. Pedersen, dan H. K. Kvist. 2006. "Blockholder Ownership: Effects on Firm Value in Market and Control Based Governance Systems". Journal of Corporate Finance, Vol. 12, No. 2, hlm: 246269.

Trinanda, S. M., M. Yahdi, dan N. Rizal. 2018. "Analisis Pengaruh Size, Profitabilitas Dan Leverage Terhadap Corporate Social Responsibility Disclosure (Studi Empiris Pada Perusahaan Jasa Sektor Property Dan Real Estate Yang Terdaftar Di Bursa Efek Indonesia Tahun 2016)". Progress Conference, Vol. 1, No. 1, hlm.

Wulanda, R. D. P. 2017. "Pengaruh Karakteristik Perusahaan Dan Corporate Governance Terhadap Publikasi Sustainability Report". JOM Fekom, Vol. 4, No. 1, hlm. 